\title{
BINOMIAL CAUSE - EFFECT RELATIONSHIP BETWEEN THE DEMOGRAPHICS AND MINING IN RURAL SETTLEMENTS IN BUCOVINA
}

DOI: http://dx.doi.org/10.18509/GBP.2017.35

UDC: 314.114:911.374.4(498)

\author{
Morar Nicoleta Ileana \\ Efros Vasile \\ "Ștefan cel Mare" University of Suceava, Romania
}

\begin{abstract}
Economic activities generates a certain dynamic in the components of a territorial system, therefore in the relations of the rural settlements. An important economic sector in the analyzed area is mining, industry that began after mid eighteenth century. The mentioned century has a special importance, the year 1775 being the one when the north-east of Romania, currently the Suceava county, became an austro-hungarian territory, being named Bucovina. The rich underground resources such as manganese, copper, uranium or salt, generated a larger industrial development after the First World War, continuing and during the communist period, because after 1989, with the change of the type of economy, to achieve a restriction of mining activities. In a territorial system, especially in a rural one, where there is not such a broad economy, the main sector of activity influenced other elements that gives him functionality. Mining specific to some rural settlements from Bucovina primarely prompted some demographic characteristics over time, based on the number and ethnic composition of the population to natural dynamics evolution and migration, as well as on the occupational structure or by age subsequent. The present qualitative and quantitative features are mostly effects of reducing mining development before 1990s, that is the subject of this study.
\end{abstract}

Keywords: territorial system, rural mining settlements, population, demographic structures, dynamic

\section{INTRODUCTION}

Territorial support of this study is the rural settlements of Cacica, Cârlibaba, Fundu Moldovei, Iacobeni and Ostra, located in Suceava County, in the mountainous region of Bucovina, where the mining industry was constituted as one of the main economic activities (fig.1). The mining activity in northern Carpathians has been practiced since the eighteenth century, since the time when that territory was under the sovereignty of the Austro-Hungarian (the occupied space was later called Bucovina) more precisely in 1784 when they started mining iron from Iacobeni and Vama by the Manz company [3]. "Exploitation of iron, bronze and silver tried in the years 1784-1797 turned out to be not cost effective. Instead, there was a good development of manganese mines from Iacobeni started in 1873 with miners brought from the county of Zips from Northern Hungary and settled there. In Cacica there started exploiting the salt deposits, with facilities for boiling salt for use by the population "[2]. The only salt deposit in north eastern Romania, situated in Cacica, has been exploited since 1791, in 1936 there was built the first factory that deals with extracting extra fine salt. At first, they used the method of obtaining salt by evaporation of salty natural springs, and later, it was produced from artificial brine. 
Iacobeni is one of mining settlements with reference for Bucovina, whose industry is exploiting the manganese, a specific activity dating back to the eighteenth century. This sector has seen a major progress after 1960s, in the context of overall development of the industry nationwide. Ores obtained here were either exported or used in renowned steel centers of Romania, Galati and Hunedoara. In 1923 there were extracted 4589 tons of salt, production doubled in 1965 and in 1971 saline exceeded 34,000 tons of salt by evaporation, the products were sent throughout the country for consumption at canneries (Tecuci, Tg. Mures, Bucharest) and export on three continents. Although currently there still is salt exploitation in this village, the scale of activity is reduced [4].

In Cârlibaba as well as in Iacobeni, they were mining manganese, which was the base of developing a real industry even since the Austro - Hungarian occupation, as mentioned before. Iacobeni was the most important center of mining and processing of manganese ores, here being sorted all of this kind in the area. 2007 was the year of cessation the mining activity in the area.

Mining of copper in Bucovina also dates back to the eighteenth century, in Fundu Moldovei area. The industrial activities developed begining with 1968, but in 2002 there was stopped the activity of copper processing plant.

Osra is the village in Bucovina where the sulphide extraction was the main mining activity, barite reserves being the most important in the country. The mining activities were stopped in 2003. The connections between the elements of a territorial system, especially rural sectors where demand is not so generous, are emphasized. So, from changes that occurred over time in the mining industry we can highlight existing demographic consequences. In this study we look at the effects on the progress or regress that industrial mining has had on the demographic component of the settlements. Therefore, we will highlight the characteristics of the population, the natural dynamics, the rate of emigration, population structure by sector, by age or ethnicity.

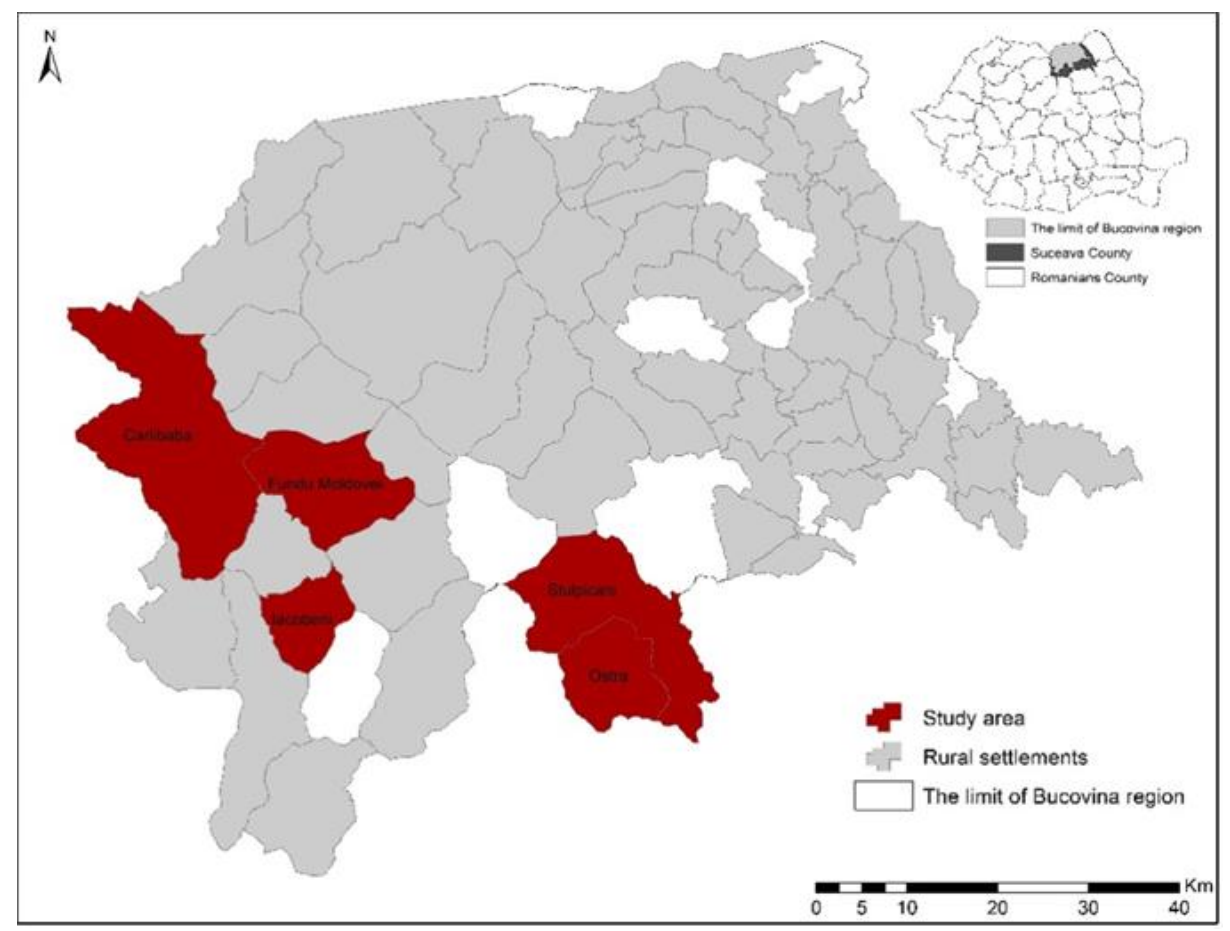

Figure 1. Study area 


\section{DATA AND METHODS}

Balancing the quantitative characteristics of the population engaged in mining activities on the one hand, and attributes both quantitative and qualitative component of action from rural settlements is based on statistical analysis on demographic indicators of the censuses of 1977, 19922002 and 2011 obtained from the Statistical Yearbook of Suceava county [5].

The number of people employed in the industry is a relevant indicator in highlighting aspects of the level and direction of settlements development.. Based on this report one can analyze and compare the relationships that exist between the number of persons employed in the mining industry and changes in the population number and settlements evolution, natural growth, migration rate, population structure by age, ethnic or occupational structure of the population.

\section{RESULTS AND DISCUSSIONS}

Analyzing the image data realised based on the statistical data (fig.2), the situation of the number of inhabitants in communes Cacica, Cârlibaba, Fundu Moldova, Iacobeni, Ostra, has a downward trend. In Cacica number of residents decreased from 4.610 inhabitants as it was in 1977 to 3.712 in 2011, the number of people falling by a percentage of $23.8 \%$. Between 1992 and 2002 census there was a slight population increase by 8.4\%. Cârlibaba village registered in censuses years a steady decrease in the number of inhabitants $(2.314$ inhabitants in 1977/1.717 inhabitants in 2011). Therefore in 2011 the population had a 25.7\% lower than in 1977. In Fundu Moldovei village population decrease was from 4.6911977 to 3.594 in 2011, so that in 35 years the population of this territorial unit fell by about $23.3 \%$. The most dramatic situation is that of Iacobeni village, where the rate of decrease in the number of inhabitants was in 2011 by $65 \%$ compared to 1977 . If the village population was 5.309 inhabitants in 1977, it dropped to 1.842 in 2012. In 35 years, period which saw the largest decline was between 1992 and 2002, when along the a 10 years period the population declined by $45.3 \%$. In the village of Ostra, the decline in population in 2011 was $40 \%$ compared to 1977.



Figure 2. The evolution of inhabitants number 


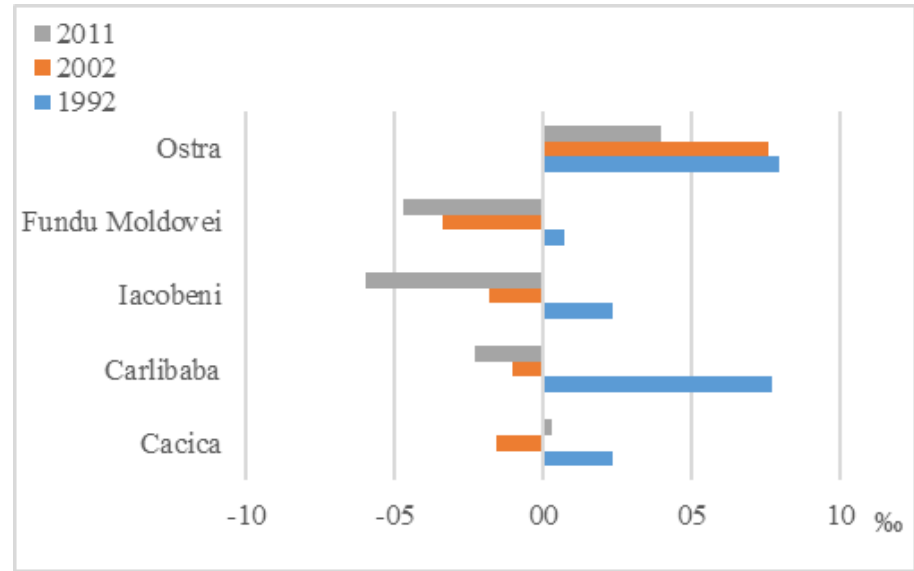

Figure 3. The natural increase of population

Regarding to natural population dynamics (fig.3), analyzed available data reveals that the natural population growth was positive for all three moments analyzed only for one village, the Ostra village. Although notice a decrease in the difference between births and deaths, falling from $7.9 \%$ in 1992, $7.4 \%$ in 2002 to $4 \%$ in 2011 . It also notes that excepting the specific of Ostra village, natural population growth of the other territorial units experienced a negative trajectory, falling below the threshold values of $0 \%$. Even if 1992 keeps positive values of natural birth rate, being over $12 \%$ (Cacica - $15.9 \%$; Cârlibaba - 15.9 \%; Iacobeni - 15.4 \%o, Fundu Moldovei - $12.9 \%$. ), over the next 10 years, the rate registered a negative increase, reaching even to $-6 \%$ (Iacobeni, 2011), or $-4.7 \%$ (Fundu Moldovei). A different situation presents Cacica village, which in 2002 had a natural birth value of $-1.6 \%$, later increasing to a value of $0.3 \%$, due to the decrease in mortality rate from $13.3 \%$ in 2002 to $11.3 \%$ in 2011, the birth rate being maintained around $11.7 \%$.

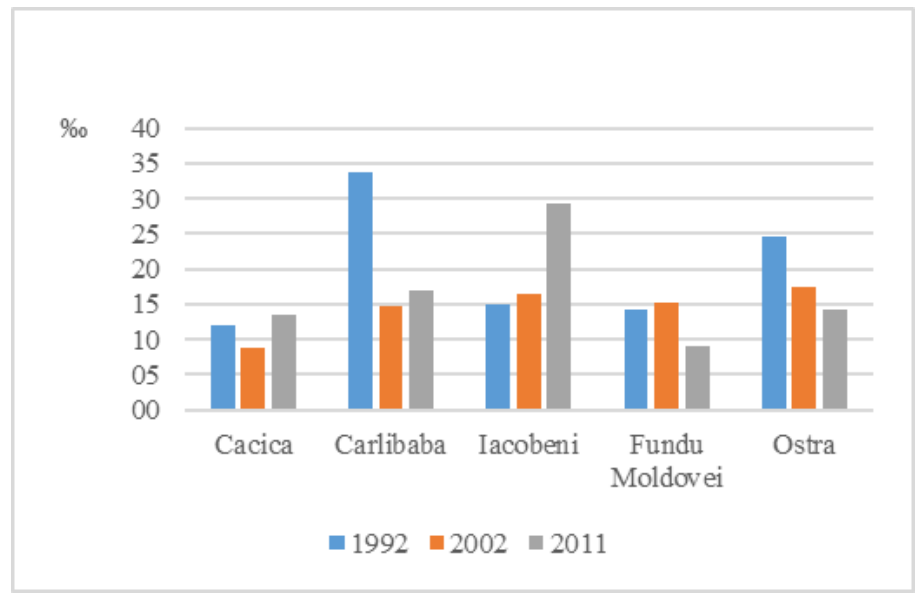

Figure 4. The emigration rate of population

Regarding the emigration rate in analyzed villages and based on given data (fig. 4), extremely high values are observed in the Cârlibaba village (33.7 \%o), when besides the political regime change that favored emigration, extractive industrial activities decreased, compared to the much higher percentage of the population employed in industry to the previous census, the difference being of 15 percent. 
An obvious case is the emigration rate of Iacobeni village, in 2011 recording the value of about $30 \%$, in 2002 the value being $16.6 \%$. The causes of this extremely large differences can also be put on the regressive nature of the industry when the population employed in this sector was reduced by about $20 \%$ in 2011 compared to 2002 . An increase in the rate of emigration is recorded at Cacica village also, where it suffered a decline from 1992 levels in 2002, from $12 \%$ to $8.8 \%$, and later, in 2011, it would see a increase to $13.5 \%$. Different circumstances shows Ostra and Fundu Moldovei villages, where the emigration rate has experienced negative trend. Thus, in Fundu Moldovei village the values decreased from about $14.5 \%$ (in 1992, 2002) to $9.2 \%$ and in the village of Ostra reduction was achieved by about 10 percent from $24.6 \%$ (1992) to $14.3 \%$ (2011).

The direct effect of existing mining industry on analyzed commune level of Bukovina space is manifesting on the structure of population on three sectors of activity. As you can see in the attached table (table 1), population from main sector has known in 35 years periods where its share evolved both positively and negatively. The highest value, specified in the reviewed moment, 2002, is 71,4\%, being registered in Cârlibaba commune. This increase was based on the decrease of the number of people which activated in secondary sector in the previous years, after the depletion of extractive activities and manganese ore processing.

Table 1. The share of employed population

\begin{tabular}{|c|c|c|c|c|}
\hline & & \multicolumn{3}{|c|}{ Economic sectors } \\
\hline & & $\begin{array}{c}\text { Primary } \\
(\%)\end{array}$ & $\begin{array}{c}\text { Secondary } \\
(\%)\end{array}$ & $\begin{array}{c}\text { Tertiary } \\
(\%)\end{array}$ \\
\hline \multirow{5}{*}{$\frac{1}{2}$} & Cacica & 57,58 & 32,34 & 10,07 \\
\hline & Carlibaba & 33,68 & 45,41 & 20,91 \\
\hline & Iacobeni & 52,57 & 36,90 & 10,54 \\
\hline & Fundu Moldovei & 22,97 & 60,46 & 16,58 \\
\hline & Ostra & 4,04 & 77,47 & 18,49 \\
\hline \multirow{5}{*}{ 亏ั } & Cacica & 51,4 & 38,1 & 10,5 \\
\hline & Carlibaba & 40,2 & 29,1 & 30,7 \\
\hline & Iacobeni & 16,1 & 56,9 & 27,0 \\
\hline & Fundu Moldovei & 40,6 & 35,9 & 23,4 \\
\hline & Ostra & 28,6 & 56,7 & 14,7 \\
\hline \multirow{5}{*}{ ฮิ } & Cacica & 48,8 & 24,7 & 26,5 \\
\hline & Carlibaba & 71,4 & 10,8 & 17,9 \\
\hline & Iacobeni & 17,0 & 44,1 & 38,9 \\
\hline & Fundu Moldovei & 46,6 & 28,8 & 24,7 \\
\hline & Ostra & 30,3 & 45,4 & 24,3 \\
\hline \multirow{5}{*}{$\overline{\bar{\vartheta}}$} & Cacica & 63,5 & 13,3 & 23,3 \\
\hline & Carlibaba & 68,8 & 8,8 & 22,4 \\
\hline & Iacobeni & 36,1 & 21,5 & 42,4 \\
\hline & Fundu Moldovei & 64,1 & 16,2 & 19,7 \\
\hline & Ostra & 48,3 & 22,6 & 29,0 \\
\hline
\end{tabular}

The lowest value of population in agricultural sector is registered in Ostra commune, in 1977 , when only $4,04 \%$ of population was working actively in this sector. This is the year 
when the secondary sectors is at his peak, $77 \%$ of residents of the commune were actively workers, being the highest value of registered in the secondary sector from the analyzed area. Due to the reduce of industrial activity, the share of population working in agriculture will be of $48,3 \%$ in 2011. High values of population working in industrial activities are specific for year 1977, in Cârlibaba commune (45,4\%) and Fundu Moldovei commune $(60,7 \%)$ or in the year of 1992 , in Iacobeni commune $(56,9 \%)$.

The third branch of economy has known a higher development after 2000, when population started to work in activities like trade, transportation or tourism. The highest value from the sphere of economic spectrum belongs to Iacobeni commune, when little under half of population $(42,4 \%)$ deals with tertiary activities.

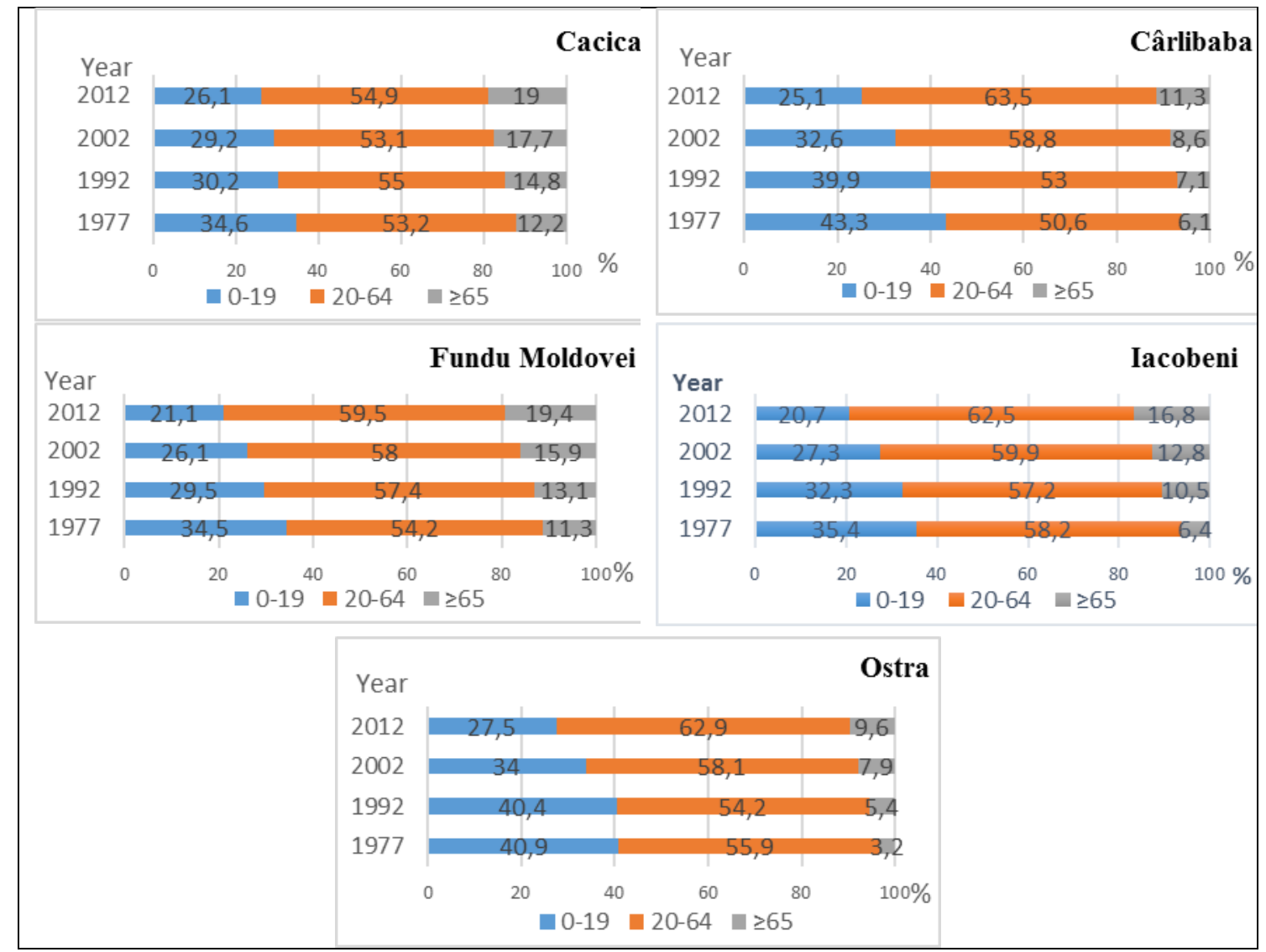

Figure 5. The age structure of population

Following the situation from the level of communes regarding the trichotomic classification of ages (fig. 5) it can be created a general rule of unidirectional evolution of the three groups of age. Referring to the youngest population (0-19 year) it can be observed the fact that the highest values are recorded in 1977, when besides the high level of industrial development specific to communist period, the situation was also favored by the pronatalist decree given in 1966. Thus, the young population of year 1977 is found in all mining rural areas from analyzed area above the value of $34 \%$, the highest value being recorded in Cârlibaba commune, where population with age under 20 is about 43,3\%. An aspect that stands out is de difference of about $18 \%$ between the youngest population of 1977 up to the lates census from 2012, the youngest population being represented by $25 \%$ of total population. The situation from the other communes is similar, although the 
differences are smaller, in Cacica commune the youngest population has decreased with 8,5\%, in Fundu Moldovei with 13,4\%, in Iacobeni with 14,7\% and in Ostra with 13,4\%. Regarding the population with age between 20 and 64, it can be observed that is followed the same trend of increasing for all major administrative territorial units. If in 1977 the values of adult population were varying between 50,6\% (Cârlibaba) and 58,2\% (Iacobeni), at the census from 2011 the values are between 54,9\% (Cacica) and 63,5\% (Cârlibaba). Therefore, the adult population has known increases of values in 2012 comparative to 1977 as follows: 1,7\% Cacica, 12,9 Cârlibaba, 5,3\% Fundu Moldovei, 4,3\% Iacobeni and 7\% Ostra.

Following the evolution of the elderly, it can be noticed the significant growth of percentages at all territorial units level. Among the analyzed settlements, Ostra commune has the lowest percent of population with age of 65 or over, precisely $9,6 \%$, the difference from year 1977 being for 6,4\%. In Cârlibaba commune, the share of elderly population has increased with $5,2 \%$, reaching $11,3 \%$ in 2012, in Caica commune the value is $19 \%$, increasing in year 2012 from 1977 by 6,8\%, in Fundu Moldovei was registered an increasing of elderly population with $8 \%$, from $11,3 \%$ in 1977 to $19,4 \%$ in 2012 . A notable observation is the fact that in 2012 the number of elderly population is extremely closed to the number of youngest population. The most dramatic situation is recorded in Iacobeni commune, where population with age over 65 has increased in 35 years with a percentage of $10,4 \%$, from $6,4 \%$ to $16,8 \%$.

Table 2. The ethnic structure share of population

\begin{tabular}{|c|c|c|c|c|c|c|}
\hline \multirow{5}{*}{ שֶׁల } & & $\begin{array}{l}\text { Romanians } \\
(\%)\end{array}$ & $\begin{array}{l}\text { Germans } \\
(\%)\end{array}$ & $\begin{array}{l}\text { Ukrainians } \\
(\%)\end{array}$ & Polish (\%) & $\begin{array}{l}\text { Other } \\
(\%\end{array}$ \\
\hline & 1977 & 66,6 & 0,4 & 3,5 & 22,7 & 6,8 \\
\hline & 1992 & 67,9 & 0,7 & 6,7 & 23,5 & 1,2 \\
\hline & 2002 & 70,6 & 1,3 & 6,4 & 21,7 & 0,1 \\
\hline & 2011 & 73,8 & 0,5 & 4,4 & 20,0 & 1,3 \\
\hline \multirow{5}{*}{ 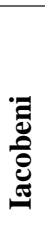 } & & $\begin{array}{l}\text { Romanians } \\
(\%)\end{array}$ & $\begin{array}{l}\text { Germans } \\
(\%)\end{array}$ & $\begin{array}{l}\text { Ukrainians } \\
(\%)\end{array}$ & $\begin{array}{l}\text { Hungarians } \\
(\%)\end{array}$ & $\begin{array}{l}\text { Other } \\
(\%)\end{array}$ \\
\hline & 1977 & 97,7 & 1,7 & 0,0 & 0,4 & 0,1 \\
\hline & 1992 & 98,6 & 1,0 & 0,2 & 0,2 & 0,0 \\
\hline & 2002 & 99,5 & 0,2 & 0,1 & 0,1 & 0,2 \\
\hline & 2011 & 97,0 & 0,3 & 0,0 & 0,0 & 2,7 \\
\hline \multirow{5}{*}{ 駦 } & & $\begin{array}{l}\text { Romanians } \\
(\%)\end{array}$ & $\begin{array}{l}\text { Germans } \\
(\%)\end{array}$ & $\begin{array}{l}\text { Ukrainians } \\
(\%)\end{array}$ & & $\begin{array}{l}\text { Other } \\
(\%)\end{array}$ \\
\hline & 1977 & 99,4 & 0,4 & 0,1 & & 0,1 \\
\hline & 1992 & 99,9 & 0,1 & 0,0 & & 0,0 \\
\hline & 2002 & 99,9 & 0,0 & 0,1 & & 0,0 \\
\hline & 2011 & 98,4 & 0,1 & 0,0 & & 1,5 \\
\hline \multirow{5}{*}{$\frac{T}{5}$} & & $\begin{array}{l}\text { Romanians } \\
\text { (\%) }\end{array}$ & $\begin{array}{l}\text { Germans } \\
(\%)\end{array}$ & $\begin{array}{l}\text { Ukrainians } \\
(\%)\end{array}$ & $\begin{array}{l}\text { Hungarians } \\
(\%)\end{array}$ & $\begin{array}{l}\text { Other } \\
(\%)\end{array}$ \\
\hline & 1977 & 99,4 & 0,0 & 0,1 & 0,3 & 0,2 \\
\hline & 1992 & 99,1 & 0,3 & 0,1 & 0,2 & 0,3 \\
\hline & 2002 & 99,6 & 0,2 & 0,1 & 0,1 & 0,1 \\
\hline & 2011 & 98,0 & 0,0 & 0,0 & 0,0 & 2,0 \\
\hline \multirow{5}{*}{ 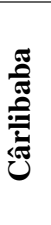 } & & $\begin{array}{l}\text { Romanians } \\
(\%)\end{array}$ & $\begin{array}{l}\text { Germans } \\
(\%)\end{array}$ & $\begin{array}{l}\text { Ukrainians } \\
(\%)\end{array}$ & $\begin{array}{l}\text { Hungarians } \\
(\%)\end{array}$ & $\begin{array}{l}\text { Other } \\
(\%)\end{array}$ \\
\hline & 1977 & 78,0 & 16,9 & 4,1 & 0,7 & 0,3 \\
\hline & 1992 & 81,2 & 12,9 & 5,6 & 0,1 & 0,1 \\
\hline & 2002 & 85,3 & 9,0 & 5,4 & 0,3 & 0,1 \\
\hline & 2011 & 89,1 & 5,1 & 4,1 & 0,0 & 1,8 \\
\hline
\end{tabular}

The diversity of ethnic structure in Bukovina is the consequence of the ethnodemographic policy that took over in the autro-hungarian domination from the occupied Romanian territory, M. Iacobescu claiming that they wanted to create a "conglomerate 
people which represents the structure of the empire in miniature"[1]. I. Nistor mentions in his paper „From the history of Bukovina” the fact that the first inhabitants of German ethnicity were the miners set in Iacobeni and Cârlibaba, Fundu Moldovei, Vama, with the purpose of infiltrating in political, socio-economic and spiritual areas [2].

As you can see in table 2, the commune with the highest ethnical diversity are Cârlibaba and Cacica. In Cârlibaba commune, in year 1977, German population was represented by $17 \%$ of the total number of inhabitants. In the following years, a decrease was registered, reaching in 2011 a percentage of 5,1\%. A significant percentage is occupied by the Ukrainian population, which has known in their 35 year increases and decreases of the number of inhabitants. If in 1977, the share of Ukrainian population was $4,1 \%$, at the following two census its value has grown, reaching 5,6\%, respectively 5,4\%, and at the next census the population registered was about $4 \%$. Even though it does not pass $1 \%$, the Hungarian population is one of the minorities that co-existed in the territory of Cârlibaba commune.

It is also noticed a high percentage of Polish population in Cacica commune, population that nowadays, as well as in the previous census, registered over $20 \%$ of the total number of inhabitants. Polish population was brought here because of their skills and experience in salt mining. Among these, Ukrainian inhabitants live, but in lower percentages. In 1977, they were about 3,5\%. By the year 1992, their number almost doubled, in year 2002 were $6,4 \%$ registered and in 2011 , they were $4,4 \%$ of the total number of inhabitants. Decreased number are registered by German population.

In Iacobeni commune, as it was mentioned earlier, the major ethnical minority is represented by Germans, who arrived in this territory in XVIII century. In 35 years, the percentage has decreased from $1,7 \%$ to $0,3 \%$.

In Ostra and Fundu Moldovei commune, even though it does not represent a great percentage from the total number of inhabitants, are registered populations of German and Ukrainian ethnicity and also Hungarian, in Ostra commune.

\section{CONCLUSION}

After the analysis achieved it was highlighted the evolution of demographic component of mining settlements due to an involution of extractive industry from Cacica, Cârlibaba, Iacobeni, Fundu Moldovei and Ostra commune. The effects which the secondary activities like extractive industry and ore processing had on the demographic element of the administrative territorial units are extremely visible.

One first effect of mining industry was the populating of settlements with German or Polish population with experience in mining activities, influences felt today, at lower intensity, the share of analyzed commune decreasing over time.

The number of population had a negative way, manifestation that characterizes in general the rural settlements from mountain areas, but the industrial regress has accelerated the increase of population number, the most visible example being the Iacobeni commune, which suffered, from our point of view, the major demographic imbalance caused by stopping the main economic activities after the 1990s.

Demographic aging is one of the effect of increased number of people aged over 65 in all municipalities, so that by reducing the two elements of the natural dynamics, the elderly population has experienced rapid growth in Fundu Moldova, Iacobeni and Cârlibaba.

Related to the occupational structure of the population in communes analyzed is an increase in the share of population employed in services, which caused the closure of 
mines and ore processing activities cease, the only town that still works this industry is Cacica.

Therefore, the domino type of relationship between mining and demography is real, the economical characteristics of settlements changing both quantitative and qualitative demographic attributes.

\section{REFERENCES}

[1]Iacobescu Mihai, From Bukowina history, Editura Academiei Română, 1993, București

[2]Nistor, I., „Bukowina history”, Editura Humanitas , 1991, Bucharest, p.307

[3]Popescu Liviu Gheorghe, Popescu Danila Alexandra, The manganese minning and polymetallic sulphides impact on the environment in the Gandacu - Suhăzelul Mare area (northwest of Suceava county, northern of Eastern Carpathians), "Ştefan cel Mare" of Suceava University Annals, Geography Section, Year XVI - 2007, p. 204

[4] Popp Nicolae, Suceava County - monography, Editura Academiei R.S. România, 1972 [5] Statistical Yearbook of Suceava county - 1977, 1992, 2002, 2011, National Institut of Statistics București, Direcția Județeană de Statistică Suceava 